\title{
ACE2 in Brain Physiology and Pathophysiology: Evidence from Transgenic Animal Models
}

\author{
Natalia Alenina ${ }^{1,2} \cdot$ Michael Bader ${ }^{1,2,3,4,5}$ iD
}

Received: 10 September 2018 / Revised: 15 October 2018 / Accepted: 8 November 2018 / Published online: 15 November 2018

๑) Springer Science+Business Media, LLC, part of Springer Nature 2018

\begin{abstract}
Angiotensin-converting enzyme 2 (ACE2) is a protein consisting of two domains, the N-terminus is a carboxypeptidase homologous to ACE and the C-terminus is homologous to collectrin and responsible for the trafficking of the neutral amino acid transporter B(0)AT1 to the plasma membrane of gut epithelial cells. The carboxypeptidase domain not only metabolizes angiotensin II to angiotensin-(1-7), but also other peptide substrates, such as apelin, kinins and morphins. In addition, the collectrin domain regulates the levels of some amino acids in the blood, in particular of tryptophan. Therefore it is of no surprise that animals with genetic alterations in the expression of ACE2 develop a diverse pattern of phenotypes ranging from hypertension, metabolic and behavioural dysfunctions, to impairments in serotonin synthesis and neurogenesis. This review summarizes the phenotypes of such animals with a particular focus on the central nervous system.
\end{abstract}

Keywords Angiotensin $\cdot$ Serotonin $\cdot$ Hypertension $\cdot$ SARS $\cdot$ Transgenic mice $\cdot$ Knockout mice

\section{Introduction}

In the last century, the renin angiotensin system (RAS) was thought to just consist of renin, metabolizing angiotensinogen to angiotensin (Ang) I which in turn is cleaved by angiotensin-converting enzyme (ACE) to the active peptide Ang II interacting with two receptors, AT1 and AT2 [1]. Other peptides of the system were known, such as Ang-(1-7), but the enzymes producing them and their receptors were elusive. While only in 2003 the receptor for Ang-(1-7), MAS, was unveiled [2], already in 2000, the main enzyme generating this heptapeptide was discovered, ACE2. ACE2 was cloned twice independently by Anthony Turner's group from

Special Issue: In Honor of Prof. Anthony J. Turner.

Michael Bader

mbader@mdc-berlin.de

1 Max-Delbrück-Center for Molecular Medicine (MDC), Robert-Rössle-Str. 10, 13125 Berlin, Germany

2 DZHK (German Center for Cardiovascular Research), Partner Site Berlin, Berlin, Germany

3 Berlin Institute of Health (BIH), Berlin, Germany

4 Charité - University Medicine, Berlin, Germany

5 Institute for Biology, University of Lübeck, Lübeck, Germany a human lymphoma cDNA library [3] and by a group at the company Millennium using a human heart library [4]. The gene consists of 18 exons and was mapped to the $\mathrm{X}$ chromosome (Xp22). ACE2 is an 805 amino acid type- 1 transmembrane protein with a molecular weight of $\sim 120 \mathrm{kDa}$. The amino-terminal domain of ACE2 has approximately $42 \%$ sequence identity with ACE, and its cytoplasmic and transmembrane domains show $48 \%$ homology to a more recently characterized protein, collectrin (Fig. 1). This, in turn, plays a critical role in the amino acid absorption of the kidney [5, 6]. Obviously, the Ace 2 gene is the result of a fusion of the Ace and the collectrin gene early in evolution [7, 8].

ACE2 is an ectoenzyme with an extracellular catalytic domain that predominantly localizes at the plasma membrane [9] and is thereby able to hydrolyze circulating peptides. Like ACE [10], it is also the subject of juxtamembranic cleavage, releasing the catalytically active ectodomain into the extracellular milieu [11]. This process is stimulated by a number of different factors (including phorbol esters) and involves the transmembrane protease ADAM17 [11, 12]. Similar to ACE, the physiological role of ectodomain cleavage of ACE2 is still unclear and the function of the circulating enzyme has not yet been identified. However, cleavage in the brain has been observed in neurogenic hypertension and is thought to be a mechanism for downregulating local ACE2 activity [12-14]. ACE2 is predominantly expressed 


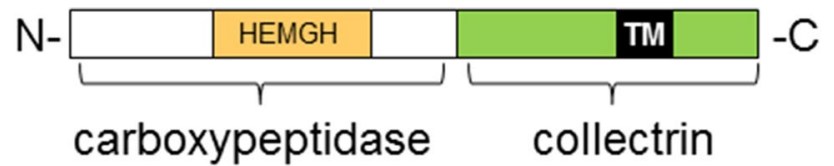

Fig. 1 Structure of ACE2 with two domains, a carboxypeptidase with homology to ACE at the N-terminus with one active site (HEMGH) and a collectrin-homologous domain at the C-terminus with a transmembrane (TM) domain

in the gastrointestinal tract, heart, kidney, lung and testes $[3,4]$. With lower levels of expression, it is also found in the brain [15].

Unlike ACE, ACE2 has only one active site (Fig. 1) and acts as a carboxypeptidase, removing the most carboxyterminal amino acid from each peptide substrate [3]. In the RAS ACE2 converts Ang I to Ang-(1-9), whose function is still unknown, and Ang II to Ang-(1-7) [16]. However, the affinity of ACE2 for Ang I is much weaker compared to ACE. Furthermore, the catalytic efficiency of ACE2 for Ang II is 400-fold greater than that for Ang I [17]. This suggests that the primary role of ACE2 is to inhibit the action of Ang II by its inactivation and the simultaneous formation of the antagonistic peptide Ang-(1-7) [1, 18, 19].

In addition to the hydrolysis of angiotensin peptides, ACE2 is also capable of cleaving various other peptides mainly with a proline residue at the penultimate position. These include apelin-13 and -36, the kinin metabolites (des$\left.\mathrm{Arg}^{9}\right)$-bradykinin and (des-Arg $\left.{ }^{10}\right)$-kallidin, neurotensin and the closely related kinetensin, as well as opioid peptides such as dynorphin A-(1-13) [17]. In contrast to ACE, however, ACE2 has no effect on bradykinin, which underlines its substrate specificity.

More recently a completely independent function of ACE2 based on its collectrin domain was discovered (Fig. 1). It is responsible for the trafficking of the neutral amino acid transporter B(0)AT1 (SLC6A19) to the plasma membrane of gut epithelial cells. Thereby it regulates the uptake of several amino acids and its deficiency leads to significant reductions in tryptophan and glycine in the blood and to an inflammatory bowel disease [20,21]. Of note, ACE2 was also chosen by the severe acute respiratory syndrome (SARS) coronavirus as receptor for its entry into cells, which represents a third, however solely pathophysiological function of the protein [22,23].

Several observations suggest a role of ACE2 in the regulation of systemic blood pressure [24, 25]. Thus, an inverse correlation of the Ace $2 \mathrm{mRNA}$ and the protein level with the occurrence of elevated blood pressure was found. In various rat strains with hypertension, such as spontaneously hypertensive rats, spontaneously hypertensive rats prone to stroke or Sabra (salt-sensitive rats prone to hypertension) rats, the Ace 2 gene maps to a quantitative trait locus for hypertension on the X-chromosome [24]. Furthermore, a reduced Ace2 transcription and protein expression could be detected in these rat models. These data are a strong indication of the involvement of ACE2 in blood pressure regulation. However, it remains to be elucidated in which tissue and by which mechanism ACE2 exerts its most relevant actions in cardiovascular physiology. As shown below the brain is a most prominent candidate.

In neurochemistry, transgenic and knockout animal models are invaluable tools to study neurohormonal systems, since they reveal effects of changes in single components of these systems on the whole physiology, as has been exemplified for the RAS [26-29]. This is particularly relevant for ACE2 with its multitude of functions and substrates. However, in each animal model with alterations in ACE2 expression the hormonal system involved in the observed phenotype needs to be sorted out. This review will summarize how animals with targeted alterations in ACE2 expression have helped to reveal its physiological and pathophysiological functions in particular in the central nervous system. The same and additional models have also been used to discover that ACE2 is a major determinant in cardiac [24, 30-32] and vascular function [33-35], atherosclerosis [36-39], metabolism [37, 40], kidney [41-44] and lung diseases [45, 46], to only name a few. However, these peripheral actions of ACE2 have previously been reviewed and are therefore not subject of this paper [19, 47-50].

\section{Transgenic Animal Models for the Study of the Central Actions of ACE2}

In several experiments mentioned below, mice with targeted deletion of the Ace 2 gene were employed. Such animals have been independently generated by several groups and different methods including classical homologous recombination in embryonic stem cells [24, 51, 52], TALENs [53] and CRISPR/Cas9 technology [46]. For some of these different mouse models phenotypes have been reported, but the results concerning blood pressure and cardiac dysfunction were not fully consistent [19]. This may be due to the different genetic backgrounds on which the mice were generated. Recently, also ACE2-deficient rats have been generated using TALENs [54]. These animals have however not yet been analyzed for central nervous system alterations, but may be very suitable in the future for this purpose due to the advantages of rats over mice in the analysis of brain physiology and behaviours [55]. Of note, due to the X-chromosomal localization of the Ace 2 gene, male animals with a hemizygous deletion of the gene $\left(\right.$ Ace $\left.2^{-/ y}\right)$ are already deficient in the enzyme.

In other studies human ACE2 was overexpressed in all neurons of transgenic mice using the synapsin promoter in either a constitutive [56] or switchable manner by flanking the transgene with loxP sites which allows cell-type specific 
ablation of the transgene by Cre recombinase expression [57].

Cell type-specific activation of ACE2 expression was achieved in another transgenic model. To this purpose, the mouse Ace 2 coding region was inserted into the Rosa26 locus with a stop-lox cassette in front of it inhibiting its expression. When a Cre-recombinase expressing mouse is bred with these animals ACE2 will be activated in the cells expressing the Cre-recombinase. Expression of Crerecombinase in the germline results in ubiquitously ACE2 overexpressing mice $[58,59]$.

\section{Central Cardiovascular Regulation}

Since ACE2 is a major determinant of Ang II levels, animals with human ACE2 overexpression in the brain exhibited a protective phenotype in several cardiovascular diseases including hypertension, cardiac hypertrophy, and chronic heart failure. When Ang II was infused peripherally by minipumps blood pressure and cardiac hypertrophy were significantly reduced in the central ACE2 overexpressing mice compared to controls [60]. Peripheral Ang II activates neurons in the circumventricular organs with a fenestrated endothelium, which in turn increase central Ang II and elicit cardiovascular effects [61]. This may be the reason that ACE2 overexpression in the brain which reduces central Ang II levels blunts the cardiovascular effects of peripheral Ang II. The same authors also reported that ACE2 overexpression in the brain attenuates the development of deoxycorticosterone acetate (DOCA)-salt hypertension, a neurogenic hypertension model with enhanced brain RAS and sympathetic activity [56]. In this model, ACE2 overexpression in neurons significantly increased nitric oxide (NO) synthase (NOS) and NO levels in the brain and blunted the Ang-II-mediated decrease in NOS expression and sympathetic activity. Moreover increased oxidative stress and cyclooxygenase mediated neuroinflammation were attenuated in transgenic mice [62]. A reduction in sympathetic nerve activity was also observed when the central ACE2 overexpressing mice were subjected to a chronic heart failure model based on permanent coronary artery ligation. This resulted in improved cardiac function in the transgenic animals [63]. Based on the use of a MAS antagonist the authors postulate that the mechanism for these effects involved a shift in the balance from central Ang II-AT1 to Ang-(1-7)/MAS signaling.

Using the model, in which the ACE2 transgene is flanked by loxP sites the role of the enzyme in the paraventricular nucleus of the hypothalamus and the subfornical organ for the antihypertensive effect after DOCA/salt treatment could be studied. The authors injected Cre-recombinase expressing adeno-associated viruses into these regions and thereby ablated transgenic ACE2 expression only there, while in other areas of the brain it remained unchanged [57]. These experiments revealed that ACE2 in both regions is important but also other areas contribute to the beneficial effect of the enzyme.

Accordingly, ACE2-deficient mice showed increased oxidative stress in the brain and autonomic dysfunctions compared to controls [64]. After Ang-II infusion and in old animals these changes were exacerbated. When ACE2 expression was restored in $A c e 2^{-/ y}$ mice by adenovirus mediated gene transfer into the paraventricular nucleus of the hypothalamus these phenotypes were attenuated [64].

Taken together these results confirm a strong antihypertensive and sympatholytic action of ACE2 in the hypothalamus which is driven by a reduction in Ang II and in increase in Ang-(1-7) levels.

\section{Stroke and Brain Injury}

In a stroke model triggered by middle cerebral artery occlusion ACE2 overexpression in the brain resulted in a decreased stroke volume and improved neurological scores in mice $[65,66]$. This was true for single transgenic mice [65] and for mice additionally overexpressing human renin and angiotensinogen with increased Ang II levels in the brain [66]. Infusion of the MAS antagonist A779 abrogated the beneficial effect of the ACE2 transgene. Moreover, the human RAS transgenic mice showed increased tissue swelling and cell death in a brain slice model with oxygen and glucose deprivation which again could be prevented by additional transgenic expression of ACE2 in neurons [67]. Using MAS antagonists, the authors revealed that ACE2 exerts its beneficial effects in ischemic brain injury by shifting the balance between Ang II and Ang-(1-7) in favor of the latter, thereby reducing local reactive oxygen species production. These results concur with numerous reports showing that the Ang-(1-7)/MAS axis exerts beneficial effects in brain injury and stroke models [67-73].

\section{SARS}

In mice transgenic for ACE2 the brain is a major target organ for SARS infection [74, 75]. The virus enters the brain primarily via the olfactory bulb resulting in rapid, transneuronal spread to other areas of the brain and finally death of the animal [76]. ACE2 is also expressed in human brain, which may be the reason that central nervous system infection by SARS is regularly observed [77].

\section{Cognition and Memory}

ACE2-deficient mice exhibit significant impairment in memory and cognition in the Morris water maze and the Y-maze assays [78]. These deficiencies could be partially rescued by administration of an AT1 receptor antagonist and 
of Ang-(1-7) arguing again for a shift in the balance between Ang II and Ang-(1-7) as major mechanism involved. This leads to a downregulation of brain-derived neurotrophic factor (BDNF) expression and an increased generation of reactive oxygen species, which both contribute to the phenotype [78]. Accordingly, Ang-(1-7) and its receptor MAS has recently been shown to be essential for memory processing in the hippocampus [79].

\section{Stress Response and Anxiety}

Mice which ubiquitously overexpress ACE2 by germlinedeletion of a stop-lox cassette were employed to study the effect of the enzyme on stress response and anxiety. Such mice spend more time on the open arms of the elevated plus maze than controls, suggesting reduced anxiety [59]. This effect was probably mediated by the Ang-(1-7)/MAS axis since it was abolished by the MAS antagonist, A779, but the authors have not tested for contributions of other ACE2 substrates or serotonin to the phenotype. Since anxiety is often accompanied by a dysregulation of the hypothalamus-pituitary-adrenal axis involved in stress response, the authors analyzed parameters of this axis in a recent followup study [80]. They found reduced plasma corticosterone and proopiomelanocortin (POMC) expression in the pituitary of ubiquitously ACE2 overexpressing mice. In the same study, ACE2 overexpression was restricted to corticotropin releasing hormone $(\mathrm{CRH})$ synthesizing cells by breeding the stop-lox ACE2 animals with a corresponding Cre-recombinase expressing mouse line [80]. Targeted overexpression of ACE2 in these cells resulted in decreased corticosterone response to restraint stress as well as decreased CRH mRNA in the hypothalamus and POMC mRNA in the pituitary. Moreover, these mice also displayed decreased anxiety-like behavior in the elevated plus maze. Together these findings indicate that ACE2 in the hypothalamus suppresses CRH synthesis and thereby the stress response and anxiety-related behavior. The mechanism may again involve the Ang-(1-7)/ MAS axis since animal models with alterations in this axis also exhibit changes in anxiety-related behaviours [81-84].

\section{Serotonin and Neurogenesis}

As mentioned above, ACE2-deficient mice present an impaired amino acid uptake in the gut leading to markedly reduced tryptophan levels in the blood [20, 21]. Serotonin is a monoamine that acts as an autacoid in the periphery and as a neurotransmitter in the brain. Since tryptophan is the precursor of serotonin synthesis, the impaired tryptophan uptake resulted in decreased serotonin synthesis and reduced levels in blood and brain [85] (Fig. 2). Besides other numerous functions in the central nervous system, serotonin is essential for exercise-induced hippocampal neurogenesis
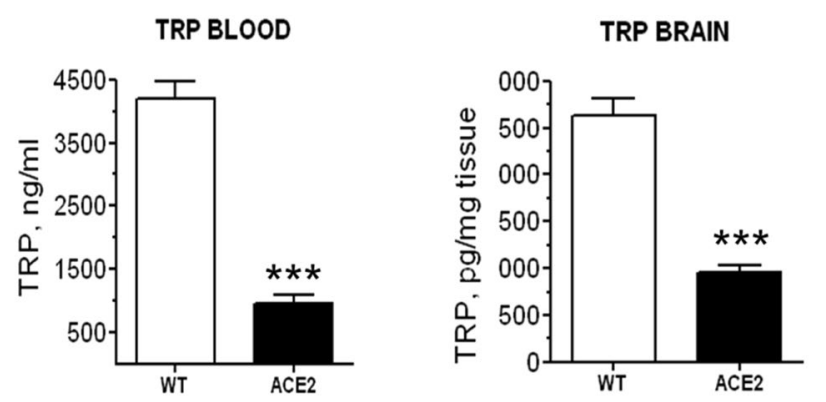

5-HT BLOOD
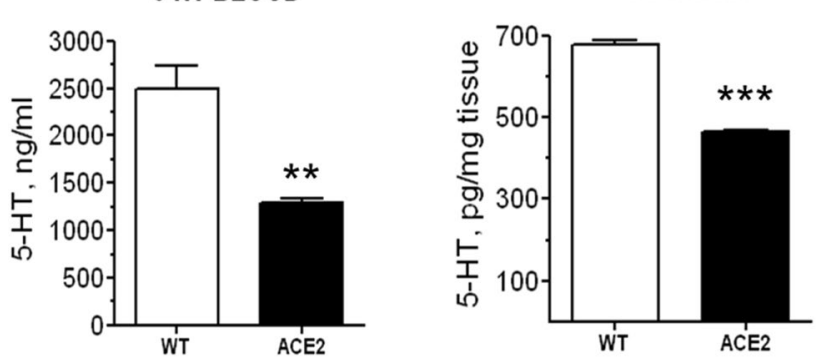

Fig. 2 Levels of tryptophan (Trp) and serotonin (5-HT) in blood and brain of wildtype (WT) and ACE2-knockout (ACE2) mice. $* * \mathrm{p}<0.01, * * * \mathrm{p}<0.001$ versus WT. Reproduced with permission from [85]

[86]. Therefore, we analyzed ACE2-deficient mice for this phenotype and discovered that exercise-induced cell proliferation in the dentate gyrus is abolished in these animals [85]. However, when we replaced serotonin in the brain by oral administration of glycyl-L-tryptophan running-induced neurogenesis was not rescued. Since we also present evidence that Ang II and Ang-(1-7) are not involved in this effect, the downstream mediator of ACE2 in the regulation of neurogenesis remains elusive [85].

\section{Conclusions and Future Directions}

Transgenic mouse models with increased or depleted ACE2 in the whole brain or certain hypothalamic nuclei were instrumental to reveal the central functions of this enzyme. Marked beneficial effects on blood pressure, cardiac hypertrophy, stress response, anxiety, cognition, brain injury and neurogenesis could be observed rendering ACE2 activation a valuable therapeutic option for several disorders. However, based on the pleiotropic actions of this protein, not all effects are necessarily due to alteration in the relative amounts of Ang II and Ang-(1-7). Changed levels of other substrates, such as apelin, neurotensin, as well as kinin and opioid peptides may also be involved in the observed consequences of alterations in central ACE2. Moreover, our discovery of reduced tryptophan and serotonin levels in the brain of ACE2-deficient mice revealed a new pathway by 
which ACE2 may influence brain function. Therefore, future therapeutic applications should be carefully evaluated for possible unwanted effects mediated by other hormone systems than the RAS.

\section{References}

1. Bader M (2010) Tissue renin-angiotensin-aldosterone systems: targets for pharmacological therapy. Ann Rev Pharmacol Toxicol 50:439-465

2. Santos RA, Simoes e Silva AC, Maric C, Silva DMR, Machado RP, de Buhr I, Heringer-Walther S, Pinheiro SVB, Lopes MT, Bader M, Mendes EP, Lemos VS, Campagnole-Santos MJ, Schultheiss HP, Speth R, Walther T (2003) Angiotensin-(1-7) is an endogenous ligand for the G-protein coupled receptor Mas. Proc Natl Acad Sci USA 100:8258-8263

3. Tipnis SR, Hooper NM, Hyde R, Karran E, Christie G, Turner AJ (2000) A human homolog of angiotensin-converting enzyme. Cloning and functional expression as a captopril-insensitive carboxypeptidase. J Biol Chem 275:33238-33243

4. Donoghue M, Hsieh F, Baronas E, Godbout K, Gosselin M, Stagliano N, Donovan M, Woolf B, Robison K, Jeyaseelan R, Breitbart RE, Acton S (2000) A novel angiotensin-converting enzyme-related carboxypeptidase (ACE2) converts angiotensin I to angiotensin 1-9. Circ Res 87:E1-E9

5. Danilczyk U, Sarao R, Remy C, Benabbas C, Stange G, Richter A, Arya S, Pospisilik JA, Singer D, Camargo SM, Makrides V, Ramadan T, Verrey F, Wagner CA, Penninger JM (2006) Essential role for collectrin in renal amino acid transport. Nature 444:1088-1091

6. Zhang H, Wada J, Hida K, Tsuchiyama Y, Hiragushi K, Shikata K, Wang H, Lin S, Kanwar YS, Makino H (2001) Collectrin, a collecting duct-specific transmembrane glycoprotein, is a novel homolog of ACE2 and is developmentally regulated in embryonic kidneys. J Biol Chem 276:17132-17139

7. Turner AJ, Hooper NM (2002) The angiotensin-converting enzyme gene family: genomics and pharmacology. Trends Pharmacol Sci 23:177-183

8. Fournier D, Luft FC, Bader M, Ganten D, Andrade-Navarro MA (2012) Emergence and evolution of the renin-angiotensin-aldosterone system. J Mol Med 90:495-508

9. Warner FJ, Lew RA, Smith AI, Lambert DW, Hooper NM, Turner AJ (2005) Angiotensin-converting enzyme 2 (ACE2), but not ACE, is preferentially localized to the apical surface of polarized kidney cells. J Biol Chem 280:39353-39362

10. Turner AJ (2003) Exploring the structure and function of zinc metallopeptidases: old enzymes and new discoveries. Biochem Soc Trans 31:723-727

11. Lambert DW, Yarski M, Warner FJ, Thornhill P, Parkin ET, Smith AI, Hooper NM, Turner AJ (2005) Tumor necrosis factor-alpha convertase (ADAM17) mediates regulated ectodomain shedding of the severe-acute respiratory syndrome-coronavirus (SARS$\mathrm{CoV}$ ) receptor, angiotensin-converting enzyme-2 (ACE2). J Biol Chem 280:30113-30119

12. Xia H, Sriramula S, Chhabra KH, Lazartigues E (2013) Brain angiotensin-converting enzyme type 2 shedding contributes to the development of neurogenic hypertension. Circ Res 113:1087-1096

13. Xu J, Sriramula S, Xia H, Moreno-Walton L, Culicchia F, Domenig O, Poglitsch M, Lazartigues E (2017) Clinical relevance and role of neuronal AT1 receptors in ADAM17-mediated ACE2 shedding in neurogenic hypertension. Circ Res 121:43-55

14. Xu J, Sriramula S, Lazartigues E (2018) Excessive glutamate stimulation impairs ACE2 activity through ADAM17-mediated shedding in cultured cortical neurons. Cell Mol Neurobiol. https ://doi.org/10.1007/s10571-018-0591-8

15. Komatsu T, Suzuki Y, Imai J, Sugano S, Hida M, Tanigami A, Muroi S, Yamada Y, Hanaoka K (2002) Molecular cloning, mRNA expression and chromosomal localization of mouse angiotensin-converting enzyme-related carboxypeptidase (mACE2). DNA Seq 13:217-220

16. Rice GI, Thomas DA, Grant PJ, Turner AJ, Hooper NM (2004) Evaluation of angiotensin-converting enzyme (ACE), its homologue ACE2 and neprilysin in angiotensin peptide metabolism. Biochem J 383:45-51

17. Vickers C, Hales P, Kaushik V, Dick L, Gavin J, Tang J, Godbout K, Parsons T, Baronas E, Hsieh F, Acton S, Patane M, Nichols A, Tummino P (2002) Hydrolysis of biological peptides by human angiotensin-converting enzyme-related carboxypeptidase. J Biol Chem 277:14838-14843

18. Lambert DW, Hooper NM, Turner AJ (2008) Angiotensin-converting enzyme 2 and new insights into the renin-angiotensin system. Biochem Pharmacol 75:781-786

19. Santos RAS, Sampaio WO, Alzamora AC, Motta-Santos D, Alenina N, Bader M, Campagnole-Santos MJ (2018) The ACE2/ angiotensin-(1-7)/MAS axis of the renin-angiotensin system: focus on angiotensin-(1-7). Physiol Rev 98:505-553

20. Hashimoto T, Perlot T, Rehman A, Trichereau J, Ishiguro H, Paolino M, Sigl V, Hanada T, Hanada R, Lipinski S, Wild B, Camargo SM, Singer D, Richter A, Kuba K, Fukamizu A, Schreiber S, Clevers H, Verrey F, Rosenstiel P, Penninger JM (2012) ACE2 links amino acid malnutrition to microbial ecology and intestinal inflammation. Nature 487:477-481

21. Singer D, Camargo SM, Ramadan T, Schafer M, Mariotta L, Herzog B, Huggel K, Wolfer D, Werner S, Penninger JM, Verrey F (2012) Defective intestinal amino acid absorption in Ace 2 null mice. Am J Physiol Gastrointest Liver Physiol 303:G686-G695

22. Li W, Moore MJ, Vasilieva N, Sui J, Wong SK, Berne MA, Somasundaran M, Sullivan JL, Luzuriaga K, Greenough TC, Choe H, Farzan M (2003) Angiotensin-converting enzyme 2 is a functional receptor for the SARS coronavirus. Nature 426:450-454

23. Turner AJ, Hiscox JA, Hooper NM (2004) ACE2: from vasopeptidase to SARS virus receptor. Trends Pharmacol Sci 25:291-294

24. Crackower MA, Sarao R, Oudit GY, Yagil C, Kozieradzki I, Scanga SE, Oliveira-dos-Santos AJ, da Costa J, Zhang L, Pei Y, Scholey J, Ferrario CM, Manoukian AS, Chappell MC, Backx PH, Yagil Y, Penninger JM (2002) Angiotensin-converting enzyme 2 is an essential regulator of heart function. Nature 417:822-828

25. Yagil Y, Yagil C (2003) Hypothesis: ACE2 modulates blood pressure in the mammalian organism. Hypertension 41:871-873

26. Bader M, Bohnemeier H, Zollmann FS, Lockley-Jones OE, Ganten D (2000) Transgenic animals in cardiovascular disease research. Exp Physiol 85:713-731

27. Mori MAS, Bader M, Pesquero JB (2008) Genetically altered animals in the study of the metabolic functions of peptide hormone systems. Curr Opin Nephrol Hypertens 17:11-17

28. Bader M (2010) Rat models of cardiovascular diseases. Methods Mol Biol 597:403-414

29. Alenina N, Xu P, Rentzsch B, Patkin EL, Bader M (2008) Genetically altered animal models for Mas and angiotensin-(1-7). Exp Physiol 93:528-537

30. Donoghue M, Wakimoto H, Maguire CT, Acton S, Hales P, Stagliano N, Fairchild-Huntress V, Xu J, Lorenz JN, Kadambi V, Berul CI, Breitbart RE (2003) Heart block, ventricular tachycardia, and sudden death in ACE2 transgenic mice with downregulated connexins. J Mol Cell Cardiol 35:1043-1053

31. Patel VB, Mori J, McLean BA, Basu R, Das SK, Ramprasath T, Parajuli N, Penninger JM, Grant MB, Lopaschuk GD, Oudit GY (2016) ACE2 deficiency worsens epicardial adipose tissue 
inflammation and cardiac dysfunction in response to dietinduced obesity. Diabetes 65:85-95

32. Motta-Santos D, Dos Santos RA, Oliveira M, Qadri F, Poglitsch M, Mosienko V, Kappes BL, Campagnole-Santos MJ, Penninger M, Alenina N, Bader M (2016) Effects of ACE2 deficiency on physical performance and physiological adaptations of cardiac and skeletal muscle to exercise. Hypertens Res 39:506-512

33. Rentzsch B, Todiras M, Iliescu R, Popova E, Campos LA, Oliveira ML, Baltatu OC, Santos RA, Bader M (2008) Transgenic ACE2 overexpression in vessels of SHRSP rats reduces blood pressure and improves endothelial function. Hypertension 52:967-973

34. Lovren F, Pan Y, Quan A, Teoh H, Wang G, Shukla PC, Levitt KS, Oudit GY, Al-Omran M, Stewart DJ, Slutsky AS, Peterson MD, Backx PH, Penninger JM, Verma S (2008) Angiotensin converting enzyme-2 confers endothelial protection and attenuates atherosclerosis. Am J Physiol Heart Circ Physiol 295:H1377-H1384

35. Rabelo LA, Todiras M, Nunes-Souza V, Qadri F, Szijarto IA, Gollasch M, Penninger JM, Bader M, Santos RA, Alenina N (2016) Genetic deletion of ACE2 induces vascular dysfunction in C57BL/6 mice: role of nitric oxide imbalance and oxidative stress. PLoS ONE 11:e0150255

36. Thomas MC, Pickering RJ, Tsorotes D, Koitka A, Sheehy K, Bernardi S, Toffoli B, Nguyen-Huu TP, Head GA, Fu Y, Chin-Dusting J, Cooper ME, Tikellis C (2010) Genetic Ace2 deficiency accentuates vascular inflammation and atherosclerosis in the ApoE knockout mouse. Circ Res 107:888-897

37. Niu MJ, Yang JK, Lin SS, Ji XJ, Guo LM (2008) Loss of angiotensin-converting enzyme 2 leads to impaired glucose homeostasis in mice. Endocrine 34:56-61

38. Sahara M, Ikutomi M, Morita T, Minami Y, Nakajima T, Hirata Y, Nagai R, Sata M (2014) Deletion of angiotensin-converting enzyme 2 promotes the development of atherosclerosis and arterial neointima formation. Cardiovasc Res 101:236-246

39. Thatcher SE, Zhang X, Howatt DA, Yiannikouris F, Gurley SB, Ennis T, Curci JA, Daugherty A, Cassis LA (2014) Angiotensin-Converting enzyme 2 decreases formation and severity of angiotensin II-induced abdominal aortic aneurysms. Arterioscler Thromb Vasc Biol 34:2617-2623

40. Cao X, Yang FY, Xin Z, Xie RR, Yang JK (2014) The ACE2/ Ang-(1-7)/Mas axis can inhibit hepatic insulin resistance. Mol Cell Endocrinol 393:30-38

41. Oudit GY, Herzenberg AM, Kassiri Z, Wong D, Reich H, Khokha R, Crackower MA, Backx PH, Penninger JM, Scholey JW (2006) Loss of angiotensin-converting enzyme-2 leads to the late development of angiotensin II-dependent glomerulosclerosis. Am J Pathol 168:1808-1820

42. Yang XH, Wang YH, Wang JJ, Liu YC, Deng W, Qin C, Gao JL, Zhang LY (2012) Role of angiotensin-converting enzyme (ACE and ACE2) imbalance on tourniquet-induced remote kidney injury in a mouse hindlimb ischemia-reperfusion model. Peptides 36:60-70

43. Fang F, Liu GC, Zhou X, Yang S, Reich HN, Williams V, Hu A, Pan J, Konvalinka A, Oudit GY, Scholey JW, John R (2013) Loss of ACE2 exacerbates murine renal ischemia-reperfusion injury. PLoS ONE 8:e71433

44. Nadarajah R, Milagres R, Dilauro M, Gutsol A, Xiao F, Zimpelmann J, Kennedy C, Wysocki J, Batlle D, Burns KD (2012) Podocyte-specific overexpression of human angiotensin-converting enzyme 2 attenuates diabetic nephropathy in mice. Kidney Int 82:292-303

45. Imai Y, Kuba K, Rao S, Huan Y, Guo F, Guan B, Yang P, Sarao R, Wada T, Leong-Poi H, Crackower MA, Fukamizu A, Hui CC, Hein L, Uhlig S, Slutsky AS, Jiang C, Penninger JM (2005) Angiotensin-converting enzyme 2 protects from severe acute lung failure. Nature 436:112-116
46. Zhang J, Dong J, Martin M, He M, Gongol B, Marin TL, Chen L, Shi X, Yin Y, Shang F, Wu Y, Huang HY, Zhang J, Zhang Y, Kang J, Moya EA, Huang HD, Powell FL, Chen Z, Thistlethwaite PA, Yuan ZY, Shyy JY (2018) AMPK phosphorylation of ACE2 in endothelium mitigates pulmonary hypertension. Am J Respir Crit Care Med 198:509-520

47. Santos RA, Ferreira AJ, Verano-Braga T, Bader M (2013) Angiotensin-converting enzyme 2 , angiotensin-(1-7) and Mas: new players of the renin-angiotensin system. J Endocrinol 216:R1-R17

48. Patel VB, Zhong JC, Grant MB, Oudit GY (2016) Role of the ACE2/angiotensin 1-7 axis of the renin-angiotensin system in heart failure. Circ Res 118:1313-1326

49. Williams VR, Scholey JW (2018) Angiotensin-converting enzyme 2 and renal disease. Curr Opin Nephrol Hypertens 27:35-41

50. Danilczyk U, Penninger JM (2006) Angiotensin-converting enzyme II in the heart and the kidney. Circ Res 98:463-471

51. Gurley SB, Allred A, Le TH, Griffiths R, Mao L, Philip N, Haystead TA, Donoghue M, Breitbart RE, Acton SL, Rockman HA, Coffman TM (2006) Altered blood pressure responses and normal cardiac phenotype in ACE2-null mice. J Clin Investig 116:2218-2225

52. Yamamoto K, Ohishi M, Katsuya T, Ito N, Ikushima M, Kaibe M, Tatara Y, Shiota A, Sugano S, Takeda S, Rakugi H, Ogihara T (2006) Deletion of angiotensin-converting enzyme 2 accelerates pressure overload-induced cardiac dysfunction by increasing local angiotensin II. Hypertension 47:718-726

53. Liu C, Xiao L, Li F, Zhang H, Li Q, Liu H, Fu S, Li C, Zhang X, Wang J, Staunstrup NH, Li Y, Yang H (2015) Generation of outbred Ace 2 knockout mice by RNA transfection of TALENs displaying colitis reminiscent pathophysiology and inflammation. Transgenic Res 24:433-446

54. Zhang ZZ, Cheng YW, Jin HY, Chang Q, Shang QH, Xu YL, Chen LX, Xu R, Song B, Zhong JC (2017) The sirtuin 6 prevents angiotensin II-mediated myocardial fibrosis and injury by targeting AMPK-ACE2 signaling. Oncotarget 8:72302-72314

55. Homberg JR, Wohr M, Alenina N (2017) Comeback of the rat in biomedical research. ACS Chem Neurosci 8:900-903

56. Feng Y, Xia H, Cai Y, Halabi CM, Becker LK, Santos RA, Speth RC, Sigmund CD, Lazartigues E (2010) Brain-selective overexpression of human angiotensin-converting enzyme type 2 attenuates neurogenic hypertension. Circ Res 106:373-382

57. Xia H, de Queiroz TM, Sriramula S, Feng Y, Johnson T, Mungrue IN, Lazartigues E (2015) Brain ACE2 overexpression reduces DOCA-salt hypertension independently of endoplasmic reticulum stress. Am J Physiol Regul Integr Comp Physiol 308:R370-R378

58. Qi YF, Zhang J, Wang L, Shenoy V, Krause E, Oh SP, Pepine CJ, Katovich MJ, Raizada MK (2016) Angiotensin-converting enzyme 2 inhibits high-mobility group box 1 and attenuates cardiac dysfunction post-myocardial ischemia. J Mol Med (Berlin) 94:37-49

59. Wang L, de Kloet AD, Pati D, Hiller H, Smith JA, Pioquinto DJ, Ludin JA, Oh SP, Katovich MJ, Frazier CJ, Raizada MK, Krause EG (2016) Increasing brain angiotensin converting enzyme 2 activity decreases anxiety-like behavior in male mice by activating central Mas receptors. Neuropharmacology 105:114-123

60. Feng Y, Hans C, Mcllwain E, Varner KJ, Lazartigues E (2012) Angiotensin-converting enzyme 2 over-expression in the central nervous system reduces angiotensin-II-mediated cardiac hypertrophy. PLoS ONE 7:e48910

61. Baltatu O, Silva JA Jr, Ganten D, Bader M (2000) The brain reninangiotensin system modulates angiotensin II-induced hypertension and cardiac hypertrophy. Hypertension 35:409-412

62. Sriramula S, Xia H, Xu P, Lazartigues E (2015) Brain-targeted angiotensin-converting enzyme 2 overexpression attenuates neurogenic hypertension by inhibiting cyclooxygenase-mediated inflammation. Hypertension 65:577-586 
63. Xiao L, Gao L, Lazartigues E, Zucker IH (2011) Brain-selective overexpression of angiotensin-converting enzyme 2 attenuates sympathetic nerve activity and enhances baroreflex function in chronic heart failure. Hypertension 58:1057-1065

64. Xia H, Suda S, Bindom S, Feng Y, Gurley SB, Seth D, Navar LG, Lazartigues E (2011) ACE2-mediated reduction of oxidative stress in the central nervous system is associated with improvement of autonomic function. PLoS ONE 6:e22682

65. Chen J, Zhao Y, Chen S, Wang J, Xiao X, Ma X, Penchikala M, Xia H, Lazartigues E, Zhao B, Chen Y (2014) Neuronal overexpression of ACE2 protects brain from ischemia-induced damage. Neuropharmacology 79:550-558

66. Zheng JL, Li GZ, Chen SZ, Wang JJ, Olson JE, Xia HJ, Lazartigues E, Zhu YL, Chen YF (2014) Angiotensin converting enzyme 2/Ang-(1-7)/mas axis protects brain from ischemic injury with a tendency of age-dependence. CNS Neurosci Ther 20:452-459

67. Zheng J, Li G, Chen S, Bihl J, Buck J, Zhu Y, Xia H, Lazartigues E, Chen Y, Olson JE (2014) Activation of the ACE2/Ang-(1-7)/ Mas pathway reduces oxygen-glucose deprivation-induced tissue swelling, ROS production, and cell death in mouse brain with angiotensin II overproduction. Neuroscience 273:39-51

68. Bennion DM, Jones CH, Donnangelo LL, Graham JT, Isenberg JD, Dang AN, Rodriguez V, Sinisterra RDM, Sousa FB, Santos RAS, Sumners C (2018) Neuroprotection by post-stroke administration of an oral formulation of angiotensin-(1-7) in ischaemic stroke. Exp Physiol 103:916-923

69. Bennion DM, Haltigan E, Regenhardt RW, Steckelings UM, Sumners C (2015) Neuroprotective mechanisms of the ACE2angiotensin-(1-7)-Mas axis in stroke. Curr Hypertens Rep 17:3

70. Regenhardt RW, Desland F, Mecca AP, Pioquinto DJ, Afzal A, Mocco J, Sumners C (2013) Anti-inflammatory effects of angiotensin-(1-7) in ischemic stroke. Neuropharmacology 71:154-163

71. Mecca AP, Regenhardt RW, O'Connor TE, Joseph JP, Raizada MK, Katovich MJ, Sumners C (2011) Cerebroprotection by angiotensin-(1-7) in endothelin-1-induced ischaemic stroke. Exp Physiol 96:1084-1096

72. Regenhardt RW, Mecca AP, Desland F, Ritucci-Chinni PF, Ludin JA, Greenstein D, Banuelos C, Bizon JL, Reinhard MK, Sumners C (2014) Centrally administered angiotensin-(1-7) increases the survival of stroke prone spontaneously hypertensive rats. Exp Physiol 99:442-453

73. Jiang T, Gao L, Guo J, Lu J, Wang Y, Zhang Y (2012) Suppressing inflammation by inhibiting the NF-kappaB pathway contributes to the neuroprotective effect of angiotensin-(1-7) in rats with permanent cerebral ischaemia. Br J Pharmacol 167:1520-1532

74. Yang XH, Deng W, Tong Z, Liu YX, Zhang LF, Zhu H, Gao H, Huang L, Liu YL, Ma CM, Xu YF, Ding MX, Deng HK, Qin C (2007) Mice transgenic for human angiotensin-converting enzyme 2 provide a model for SARS coronavirus infection. Comp Med 57:450-459

75. McCray PB Jr, Pewe L, Wohlford-Lenane C, Hickey M, Manzel L, Shi L, Netland J, Jia HP, Halabi C, Sigmund CD, Meyerholz
DK, Kirby P, Look DC, Perlman S (2007) Lethal infection of K18-hACE2 mice infected with severe acute respiratory syndrome coronavirus. J Virol 81:813-821

76. Netland J, Meyerholz DK, Moore S, Cassell M, Perlman S (2008) Severe acute respiratory syndrome coronavirus infection causes neuronal death in the absence of encephalitis in mice transgenic for human ACE2. J Virol 82:7264-7275

77. Gu J, Gong E, Zhang B, Zheng J, Gao Z, Zhong Y, Zou W, Zhan J, Wang S, Xie Z, Zhuang H, Wu B, Zhong H, Shao H, Fang W, Gao D, Pei F, Li X, He Z, Xu D, Shi X, Anderson VM, Leong AS (2005) Multiple organ infection and the pathogenesis of SARS. J Exp Med 202:415-424

78. Wang XL, Iwanami J, Min LJ, Tsukuda K, Nakaoka H, Bai HY, Shan BS, Kan-No H, Kukida M, Chisaka T, Yamauchi T, Higaki A, Mogi M, Horiuchi M (2016) Deficiency of angiotensin-converting enzyme 2 causes deterioration of cognitive function. NPJ Aging Mech Dis 2:16024

79. Lazaroni TL, Raslan AC, Fontes WR, de Oliveira ML, Bader M, Alenina N, Moraes MF, Dos Santos RA, Pereira GS (2012) Angiotensin-(1-7)/Mas axis integrity is required for the expression of object recognition memory. Neurobiol Learn Mem 97:113-123

80. Wang LA, de Kloet AD, Smeltzer MD, Cahill KM, Hiller H, Bruce EB, Pioquinto DJ, Ludin JA, Katovich MJ, Raizada MK, Krause EG (2018) Coupling corticotropin-releasing-hormone and angiotensin converting enzyme 2 dampens stress responsiveness in male mice. Neuropharmacology 133:85-93

81. Walther T, Balschun D, Voigt JP, Fink H, Zuschratter W, Birchmeier C, Ganten D, Bader M (1998) Sustained long term potentiation and anxiety in mice lacking the Mas protooncogene. J Biol Chem 273:11867-11873

82. Kangussu LM, Almeida-Santos AF, Bader M, Alenina N, Fontes MA, Santos RA, Aguiar DC, Campagnole-Santos MJ (2013) Angiotensin-(1-7) attenuates the anxiety and depression-like behaviors in transgenic rats with low brain angiotensinogen. Behav Brain Res 257:25-30

83. Kangussu LM, Almeida-Santos AF, Moreira FA, Fontes MAP, Santos RAS, Aguiar DC, Campagnole-Santos MJ (2017) Reduced anxiety-like behavior in transgenic rats with chronically overproduction of angiotensin-(1-7): role of the Mas receptor. Behav Brain Res 331:193-198

84. Moura SD, Ribeiro MF, Limborco-Filho M, de Oliveira ML, Hamamoto D, Xavier CH, Moreira FA, Santos RA, CampagnoleSantos MJ, Peliky Fontes MA (2017) Chronic overexpression of angiotensin-(1-7) in rats reduces cardiac reactivity to acute stress and dampens anxious behavior. Stress 20:189-196

85. Klempin F, Mosienko V, Matthes S, Villela DC, Todiras M, Penninger JM, Bader M, Santos RAS, Alenina N (2018) Depletion of angiotensin-converting enzyme 2 reduces brain serotonin and impairs the running-induced neurogenic response. Cell Mol Life Sci 75:3625-3634

86. Klempin F, Beis D, Mosienko V, Kempermann G, Bader M, Alenina N (2013) Serotonin is required for exercise-induced adult hippocampal neurogenesis. J Neurosci 33:8270-8275 